\title{
Penyelesaian Multiple Trip Heterogeneous Fix Fleet Vehicle Routing Problem (MTHFFVRP) Menggunakan Algoritma Sweep untuk Mendapatkan Optimasi Rute Distribusi LPG 3 kg di PT. Gending Gemilang
}

\author{
${ }^{1}$ Arief Irfan Syah Tjaja, ${ }^{2}$ Saiful Farisin \\ 1,2Program Studi Teknik Industri, Fakultas Teknologi Industri, Institut Teknologi Nasional, \\ Bandung, Indonesia \\ E-mail: arief@itenas.ac.id ${ }^{1}$,fnsaiful@gmail.com²
}

Received 24 March 2021 | Revised 18 May 2021 | Accepted

\begin{abstract}
ABSTRAK
Distibusi merupakan suatu kegiatan menyalurkan produk dari satu tempat ke tempat lainnya. PT. Gending Gemilang merupakan suatu perusahaan yang bergerak dibidang distributor Liquefied Petroleum Gas (LPG) $3 \mathrm{~kg}$, setiap harinya perusahaan diharuskan untuk memenuhi permintaan ke 29 pangkalan yang dimiliki perusahaan. Perusahaan memiliki 2 jenis armada yaitu truk sebanyak 4 unit dan L300 sebanyak 3 unit dengan kapasitas setiap jenis armada berbeda beda dan setiap pangkalan memiliki alamat yang berbeda sehingga permasalahan penentuan rute masuk kedalam Multiple Trips Heterogeneous Fix Fleet Routing Problem (MTHFFVRP). Salah satu penentuan rute yang mampu meminimumkan ongkos pengirimanan adalah dengan menggunakan algoritma sweep, algoritma ini bekerja dengan cara melakukan proses clustering berdasarkan urutan sudut polar setiap pangkalan, pada penelitian ini jenis algoritma sweep yang digunakan adalah backward sweep sehingga untuk pembuatan cluster dimulai dari pangkalan yang memiliki sudut polar terbesar menuju pangkalan yang memliki sudut polar terkecil. Dari hasil penelitian menunjukan pembuatan rute menggunakan algoritma sweep mampu melakukan penghematan secara signifikan terhadap rute perusahaan saat ini
\end{abstract}

Kata kunci: Distribusi, Vehicle Routing Problem, Multiple Trips Heterogenous Fix Fleet Routing Problem (MTHFFVRP), Algoritma sweep

\begin{abstract}
Distribution is an activity to distribute products from one place to another. PT. Gending Gemilang is a company engaged in the distribution of $3 \mathrm{~kg}$ of liquefied petroleum gas or it can be called (LPG) $3 \mathrm{~kg}$, every day the company is required to fulfill requests from 29 bases owned by the company. The company has 2 types of fleets, namely 4 unit trucks and 3 unit L300 with different capacities for each type of fleet and each base has a different address so that the problem of determining routes enters the Multiple Trips Heterogeneous Fix Fleet Routing Problem (MTHFFVRP). Determination to minimize the shipping cost of the route used is the sweep algorithm, this algorithm works to carry out the clustering process based on the order of the polar angles of each base, in this study the type of sweep algorithm used is backward sweep so that clustering starts from the base with the largest polar angle towards the base that has the smallest polar angle. The research results show that route creation using the sweep algorithm is able to make significant savings on current company routes
\end{abstract}

Keywords: Distribution; Vehicle Routing Problem; Multiple Trips Heterogenous Fix Fleet Routing Problem (MTHFFVRP); Sweep Algorithm 


\section{PENDAHULUAN}

PT. Gending Gemilang merupakan perusahaan yang bergerak dibidang pendistribusian Liquefied Petroleum Gas (LPG) $3 \mathrm{~kg}$. setiap harinya perusahaan mengantarkan gas LPG ke pangkalan-pangkalan yang menjadi mitra perusahaan dengan jumlah barang yang diantarkan berbeda-beda untuk setiap pangkalannya. Setiap armada biasanya mendistribusikan barang ke beberapa pangkalan dalam satu kali keberangkatan. Saat ini perusahaan memiliki 29 pangkalan, serta 7 armada transportasi yang terdiri dari 4 truck dan 3 mobil jenis 1300 .

Pemilihan rute yang dilakukan oleh perusahaan dilakukan secara perkiraan saja, sehingga perusahaan tidak mengetahui apakah rute pengiriman yang ditetapkan saat ini sudah optimal atau tidak. Permasalahan mencari rute terbaik untuk meminimasi jarak dan total biaya pengiriman dari perusahaan ke pangkalan-pangkalan yang tersebar dengan demand yang berbeda dan serta harus 'tersapu' habis biasa disebut dengan Vehicle Routing Problem (VRP). VRP adalah masalah penentuan rute kendaraan dalam mendistribusikan barang dari tempat produksi (depot) ke konsumen dengan tujuan meminimumkan total jarak tempuh kendaraan. Secara sederhana, VRP merupakan permasalahan penentuan rute-rute dari sejumlah kendaraan yang dimulai dari tempat produksi atau depot utama ke setiap konsumennya dengan lokasi yang berbeda dan jumlah permintaan tertentu. VRP dapat didefinisikan sebagai suatu pencarian solusi yang meliputi penentuan sejumlah rute, dimana masingmasing rute dilalui oleh satu kendaraan yang berawal dan berakhir di depot asalnya, sehingga kebutuhan/permintaan semua pelanggan terpenuhi dengan tetap memenuhi kendala operasional yang ada, juga dengan meminimalisasi biaya transportasi global [1]. Dalam hal ini PT. Gending Gemilang mempunyai keterbatasan yaitu armada yang dimiliki oleh perusahaan mempunyai kapasitas angkut yang berbeda (Truck dengan 1300) dengan jumlah armada yang dimiliki bersifat tetap sebesar 4 armada truck dan 3 armada L300 dan armada L300 diperbolehkan untuk melakakukan lebih dari satu kali pemberangkatan dalam satu harinya dengan rute yang berbeda sehingga permasalahan pencarian rute terbaik (VRP) masuk kedalam kategori Multiple Trips Heterogeneous Fixed Fleet Routing Problem (MTHFFVRP), MTHFFVRP merupakan kelas VRP dimana kapasitas armada bersifat heterogen dan jumlah armada yang digunakan bersifat tetap (adanya keterbatasan jumlah kendaraan yang tersedia) sehingga karena adanya keterbatasan jumlah kendaraan yang tersedia maka masing-masing kendaraan dapat melakukan pengiriman lebih dari satu kali dalam periode perencanaan tertentu (Multiple Trip) [1]

Berdasarkan permasalahan diatas tentunya perusahaan memerlukan algoritma yang tepat untuk menentukan rute distribusi yang baik untuk perusahaan. Algoritma yang dapat digunakan untuk menyelesaikan MTHFFVRP ialah algoritma sweep. Algoritma sweep ialah algoritma yang sederhana dalam perhitungannya, bahkan untuk permasalahan yang bersifat kompleks. Algoritma sweep digunakan karena algoritma sweep lebih menghasilkan solusi yang sesuai dengan keadaan di lapangan seperti adanya kapasitas angkut yang berbeda antar armada. Algoritma sweep sendiri terbagi menjadi dua jenis yaitu forward sweep dan backward sweep. Forward sweep ialah algoritma sweep dengan proses clustering maju atau dengan kata lain dimulai dari sudut polar terkecil ke sudut polar terbesar, sedangkan backward sweep merupakan algoritma sweep dengan proses clustering mundur atau dengan kata lain dimulai dari sudut polar terbesar menuju sudut polar terkecil

\section{METODOLOGI}

\subsection{Identifikasi Masalah}

PT. Gending Gemilang merupakan perusahaan yang bergerak dibidang pendistribusian gas LPG $3 \mathrm{~kg}$. setiap harinya perusahaan mengantarkan gas lpg ke pangkalan-pangkalan gas lpg yang menjadi mitra perusahaan dengan jumlah barang yang diantarkan berbeda-beda untuk setiap pangkalannya. Setiap armada biasanya mendistribusikan barang ke beberapa pangkalan dalam satu kali keberangkatan. Saat ini perusahaan memiliki 29 pangkalan, serta 7 armada transportasi yang terdiri dari 4 truck dan 3 mobil jenis 1300 . 
Pemilihan rute yang dilakukan oleh perusahaan dilakukan secara perkiraan saja, sehingga perusahaan tidak mengetahui apakah rute pengiriman yang ditetapkan saat ini sudah optimal atau tidak. Permasalahan mencari rute terbaik untuk meminimasi jarak dari perusahaan ke pangkalan-pangkalan yang tersebar dengan demand yang berbeda dan serta harus 'tersapu' habis biasa disebut dengan VRP . Dalam hal ini PT. Gending Gemilang mempunyai keterbatasan yaitu armada yang dimiliki oleh perusahaan mempunyai kapasitas angkut yang berbeda (Truck dengan L300) dan untuk armada jenis L300 diizinkan untuk melakukan pemberangkatan lebih dari satu kali dalam setiap hari sehingga permasalahan pencarian rute terbaik (VRP) masuk kedalam kategori MTHFFVRP atau VRP dengan batasan jumlah armada heterogen tetap atau terbatas dengan jumlah pemberangkatan suatu armada lebih dari satu kali pemberangkatan [2].

\subsection{Identifikasi Penyelesaian Masalah}

PT. Gending Gemilang merupakan perusahaan yang bergerak di bidang pendistribusian gas $1 \mathrm{pg} 3 \mathrm{~kg}$. pemilihan rute distribusi yang dilakukan oleh perusahaan dilakukan secara perkiraan saja sehingga tentunya belum optimal. Perusahaan dalam hal ini mempuyai keterbatasan terkait kapasitas angkut armada yang berbeda dengan jumlah armada tersedia sebanyak 7 armada, sehingga permasalahan pencarian rute terbaik (VRP) yang terjadi pada perusahaan masuk kedalam kategori MTHFFVRP. Berdasarkan permasalahan diatas tentunya perusahaan memerlukan algoritma yang tepat untuk menentukan rute distribusi yang baik untuk perusahaan. Algoritma yang dapat digunakan untuk menyelesaikan MTHFFVRP ialah algoritma sweep. Algoritma sweep adalah algoritma yang sederhana dalam perhitungannya, bahkan untuk permasalahan yang bersifat kompleks. Algoritma sweep digunakan karena algoritma sweep lebih menghasilkan solusi yang sesuai dengan keadaan di lapangan seperti adanya kapasitas angkut yang berbeda antar armada. Langkah dalam menggunakan algoritma sweep terbagi menjadi 2 langkah yaitu pembuatan clustering pangkalan serta dilanjutkan dengan pembuatan rute untuk setiap clustering yang sudah dibuat menggunakan Algoritma Sweep [3].

\subsection{Studi Literatur}

Studi Literatur yang berhubungan dengan penelitian ini berisikan mengenai teori-teori atau pendekatan yang menunjang penelitian mulai dari teori mengenai Supply Chain yaitu jaringan perusahaanperusahaan yang secara bersama-sama bekerja untuk menciptakan dan mengantarkan suatu produk ke tangan pemakai akhir. [4], Supply Chain Management, Distribusi yang merupakan sekumpulan perantara yang terhubung erat antara satu dengan yang lainnya dalam kegiatan penyaluran produkproduk kepada konsumen.[5]. Saluran Distrbusi Transportasi, Sarana Transportasi, Manajemen Distribusi dan Transportasi, Vehicle Routing Problem (VRP), Multiple Trips Heterogenous Fleet Vehicle Routing Problem (MTHFFVRP), Algoritma Penyelesaian VRP, Algoritma Sweep, dan Algoritma Nearest Neighbour

\subsection{Pengumpulan Data}

Data data yang dikumpulkan antara lain data jumlah armada beserta kapasitas untuk setiap armadanya, data pangkalan beserta lokasi pangkalan, data permintaan untuk setiap pangkalannya, biaya pengiriman, dan data untuk rute sebelumnya untuk setiap armada.

\subsection{Pengolahan Data Algoritma Penyelesaian Vehicle Routing Problem (VRP)}

VRP dapat diselesaikan dengan menggunakan 2 jenis pendekatan, yaitu eksak dan heuristic dimana pendekatan heuristik terbagi menjadi 2 kelas yaitu heuristic klasik dan heuristik modern[1].

1.Pendekatan Eksak

Pada pendekatan eksak, dilakukan pendekatan dengan menghitung setiap solusi yang mungkin sampai satu terbaik dapat diperoleh. Secara umum penggunaan algoritma eksak untuk penyelesaian VRP akan menghabiskan waktu yang lama, dikarenakan kompleksitas penyelesaian permasalahan akan meningkat secara linier dengan semakin banyaknya permasalahan. Adapun beberapa algoritma yang dapat digunakan seperti Branch and Bound, Branch and Cut, dan Set Covering Based. 


\section{Pendekatan Heuristik Klasik}

Secara Umum, Terdapat tiga algoritma heuristic klasik VRP, yaitu :

a. Heuristik Konstruktif, yaitu penyusunan solusi yang memungkinkan dengan memperhatikan biaya solusi tersebut, tanpa dilakukan fase perbaikan.

b. Heuristik dua fase, penyelesaian masalah dibagi menjadi dua bagian, yaitu pengelompokan (clustering) rute dan pembuatan rute-rute tersebut.

c. Algoritma perbaikan, algoritma yang bertujuan untuk memperbaiki solusi yang mungkin dengan melakukan location switch dalam satu rute maupun antar rute.

\subsection{Algoritma Sweep}

Algoritma sweep adalah algoritma yang sederhana dalam perhitungannya, bahkan untuk memecahkan masalah yang cukup besar. Keakuratan algoritma ini rata-rata kesalahan perhitungannya adalah sebesar $10 \%$. Keakuratan algoritma ini adalah pada cara pembuatan jalur rutenya. Algoritma sweep terdiri dari dua tahap, pertama yaitu tahap pengelompokkan (clustering) yang mana pengelompokkan awal dilakukan dengan menggabungkan pangkalan-pangkalan dalam satu cluster berdasarkan kapasitas maksimal kendaraan. Permintaan total dalam satu cluster mungkin akan melebihi kapasitas kendaraan, karenanya beberapa pangkalan dimasukkan ke cluster berikutnya. Tahap kedua yaitu dengan menentukan urutan rute dari setiap cluster menggunakan Algoritma Nearest Neighbour[6].

Dari langkah-langkah yang dijelaskan dibawah ini, maka dapat diagram alir sebagai berikut dapat dilihat pada Gambar 1. Algoritma sweep sendiri terbagi menjadi dua jenis yaitu forward sweep dan backward sweep, forward sweep merupakan pengelompokan pelanggan dengan arah perputaran radial line dimulai dari sudut $0^{\circ}$ menuju sudut $360^{\circ}$. Arah perputaran ini biasa disebut dengan counter clockwise atau berlawanan arah jarum jam. Backward sweep memiliki arah perputaran sebaliknya. Arah perputaran radial line pada metode ke dua dalam algoritma sweep ini bergerak dari sudut $360^{\circ}$ menuju sudut 0 atau searah jarum jam. Berikut merupakan ilustrasi pengelompokan menggunakan algoritma sweep jenis forward sweep dapat dilihat pada Gambar 2 [7].

Pada Gambar 2 dapat dilihat pembuatan cluster menggunakan forward sweep dimulai dari sudut $0^{\circ}$ menuju sudut $360^{\circ}$.dengan arah perputaran berlawanan arah jarum jam, untuk pembuatan cluster menggunakan backward sweep mempunyai langkah yang sama dengan forward sweep hanya saja pada backward sweep proses pengelompokan dilakukan mulai dari $360^{\circ}$ menuju sudut $0^{\circ}$ dengan arah perputaran searah jarum jam.

Algoritma sweep dapat dilakukan dengan langkah-langkah sebagai berikut [6]:

1.Buat diagram kartesius

Pembuatan diagram kartesius dilakukan untuk semua pangkalan, dengan depot atau perusaaan sebagai pangkalan $(0,0)$ pada diagram kartesius, hal ini dikarenakan depot (perusahaan) sebagai pusat distribusi produk. Pembuatan diagram kartesius dapat dilakukan dengan bantuan aplikasi Geo Gebra.

2. Menentukan Jenis Algoritma sweep

Algoritma sweep mempunyai dua jenis yaitu backward sweep dan forward sweep, forward sweep merupakan pengelompokan pelanggan dengan arah perputaran radial line dimulai dari sudut $0^{\circ}$ menuju sudut $360^{\circ}$. Arah perputaran ini biasa disebut dengan counter clockwise atau berlawanan arah jarum jam. Backward sweep memiliki arah perputaran sebaliknya. Arah perputaran radial line pada metode ke dua dalam algoritma sweep ini bergerak dari sudut $360^{\circ}$ menuju sudut 0 atau searah jarum jam.

3. Buat koordinat polar

Pembuatan diagram polar dilakukan untuk semua pangkalan, Pembuatan diagram polar dilakukan untuk semua pangkalan, dengan depot atau perusaaan sebagai pangkalan $0^{\circ}$ pada diagram polar, hal ini dikarenakan depot (perusahaan) sebagai pusat distribusi produk. Pembuatan diagram polar dapat, dilakukan dengan bantuan aplikasi Geo Gebra 


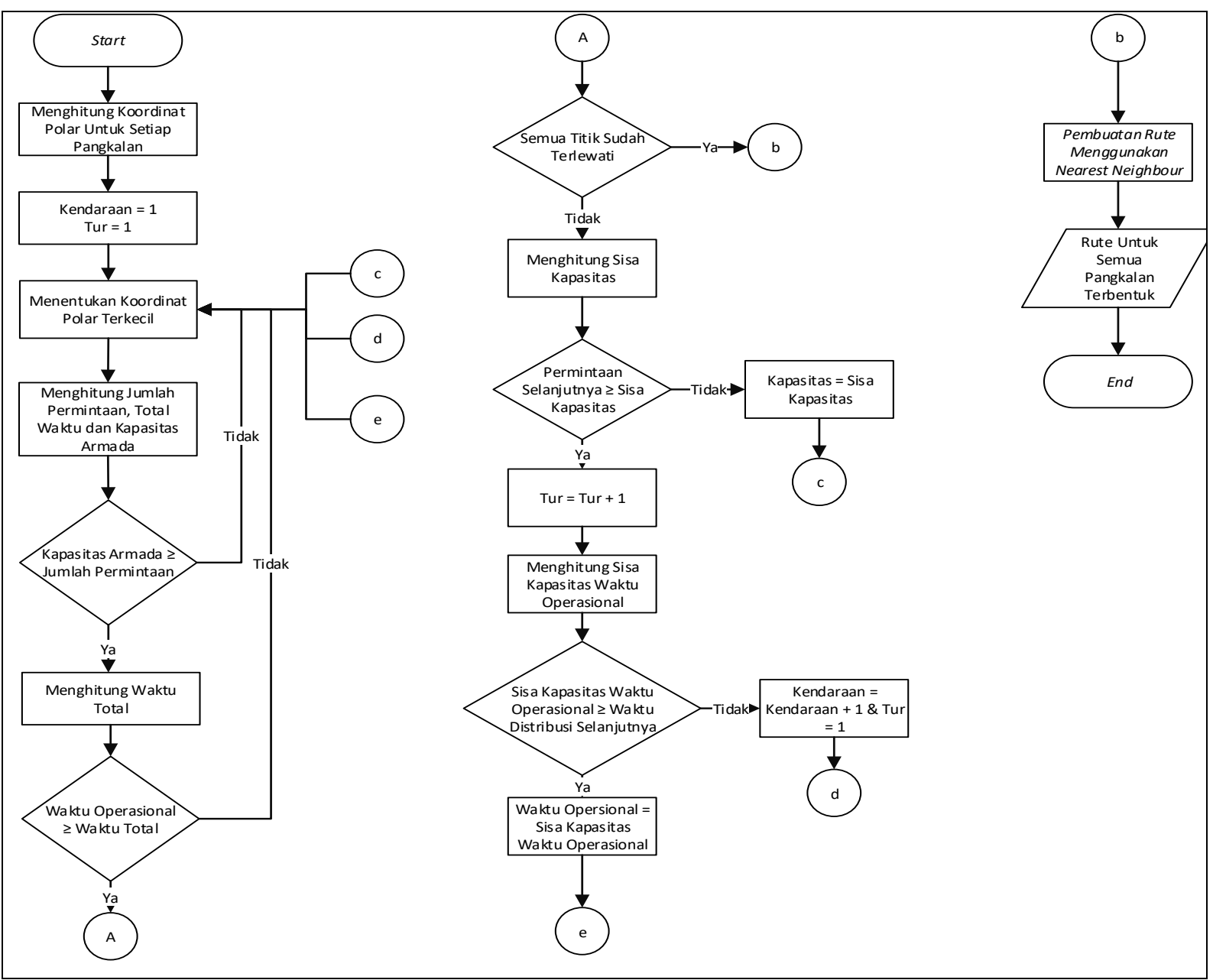

Gambar 1. Diagram alir algoritma sweep

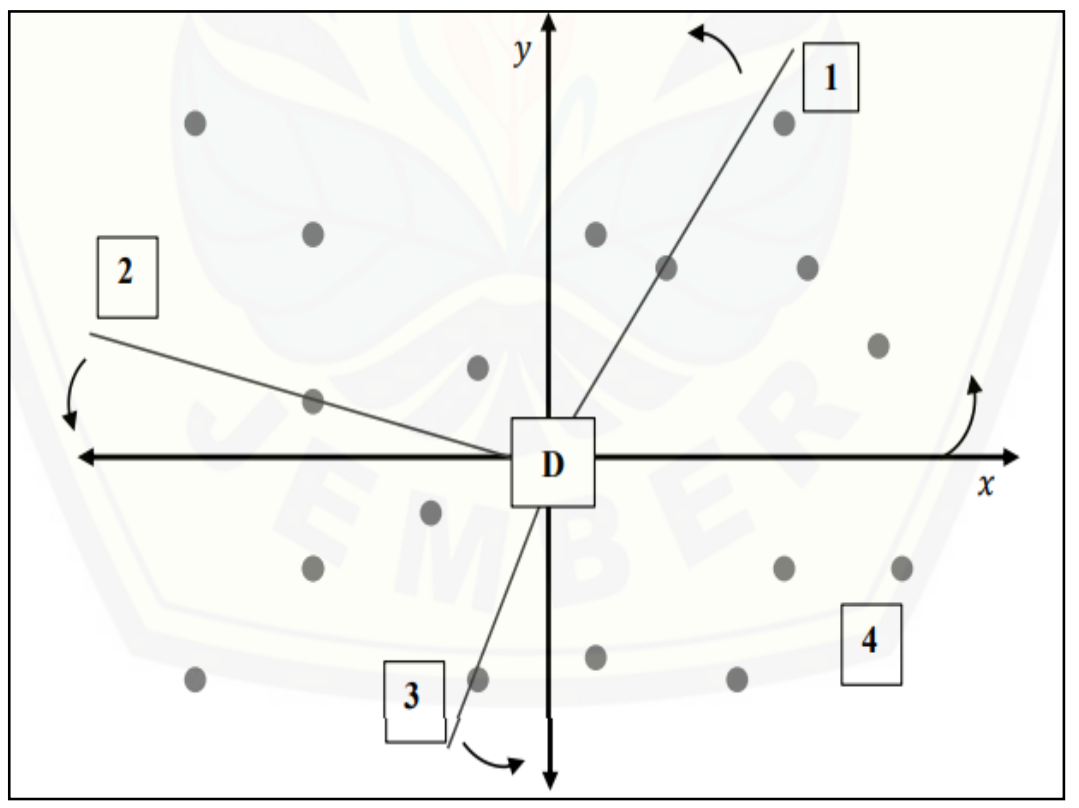

Gambar 2. Pengelompokan algoritma sweep jenis forward sweep 
4. Mengurutkan koordinar polar

Pengurutan digram polar dilakukan mulai dari pangkalan (pangkalan) yang memiliki sudut polar terkecil sampai pangkalan yang memiliki sudut polar terbesar untuk forward sweep dan pengurutan diagram polar dari pangkalan yang memiliki sudut polar terbesar sampai pangkalan yang memiliki sudut polar terkecil untuk backward sweep.

5. Menentukan Prioritas Armada yang Digunakan

Pada Heterogeneous Fleet Vehicle Routing Problerm (MTHFFVRP) setiap jenis armda memiliki kapasitas angkut yang berbeda-beda dan cost untuk setiap jenis armada sehingga perlu dilakukan penentuan armada yang diprioritaskan untuk melakukan proses distribusi, penentuan armada prioritas didapat melalui perhitungan cost yang ditimbulkan untuk setiap jenis armadanya dimana untuk cost armada sendiri terbagi menjadi dua antara lain [8] :

a. Fixed Cost

Fixed Cost merupakan ongkos tetap untuk setiap jenis armadanya, dalam pengertian lain fixed cost tidak tergantung seberapa besar jarak yang ditimbulkan oleh armada. Fixed cost sendiri biasanya berbentuk : harga sewa kendaraan, harga pembelian mobil, nilai depresiasi mobil, dsb.

b. Variable Cost

Fixed Cost merupakan ongkos yang besarannya ditentukan oleh jarak yang ditempuh untuk setiap armadanya, Variable cost sendiri biasanya berbentuk : biaya bensin. Dalam penentuan prioritas armada yang digunakan pada penelitian kali ini hanya memperhatikan biaya operasional saja seperti ongkos setiap pemberangkatan dan biaya bahan bakar

6. Menghitung Matriks Jarak \& Matriks Waktu Tempuh

Matriks jarak merupakan suatu tabel yang berisikan jarak untuk setiap pangkalannya begitupun dengan matriks waktu tempuh yang berisikan waktu untuk berpindah dari satu pangkalan ke pangkalan lainnya. Perhitungan matriks jarak \& matriks waktu pada penelitian kali ini diapat melalui bantuan aplikasi Google Maps

7. Bentuk pengelompokan (clustering)

Pembuatan pengelompokan rute (clustering) dilakukan sesuai dengan pendekatan algoritma sweep jenis backward sweep dan forward sweep, berikut merupakan langkah langkah pembuatan cluster:

a. Bentuk rute menggunakan armada yang terpilih.

b. Hitung jumlah permintaan dari pangkalan yang terpilih. Jika permintaan $>$ kapasitas kendaraan maka kembali ke poin a dengan mencari pangkalan rute yang permintaannya tidak melebihi kapasitas kendaraan. Jika permintaan < kapasitas kendaraan maka lanjut ke poin c.

c. Menghitung waktu tempuh dengan rumus.

Perhitungan waktu tempuh dapat menggunakan bantuan aplikasi Google Maps

d. Menghitung waktu penyelesaian total dengan rumus.

$$
\begin{array}{r}
\text { Waktu Total }=\quad \text { Waktu loading }+ \text { Waktu unloading }+ \text { waktu tempuh }+ \\
\text { waktu administrasi (jika ada) }
\end{array}
$$

e. Membandingkan total waktu penyelesaian dengan jam kerja yang tersedia jika melebihi kembali ke poin a, jika tidak lanjut ke poin selanjutnya.

f. Lakukan semua proses secara berulang hingga seluruh pangkalan teralokasikan.

8. Pastikan semua pangkalan (pangkalan) sudah masuk kedalam rute

Proses ini dilakukan untuk memvalidasi apakah semua pangkalan sudah mempunyai rutenya (cluster) masing masing, apabila ada pangkalan yang belum mempunyai cluster maka kembali ke langkah 4, apabila sudah maka lanjut ke langkah selanjutnya.

9. Penentuan rute untuk masing masing

Setelah semua pangkalan sudah masuk kedalam setiap clustering maka tahap selanjutnya adalah membuat rute optimal untuk masing-masing clustering menggunakan algoritma nearest neighbour. Langkah pengerjaan pembuatan rute menggunakan algoritma nearest neighbour adalah sebagai berikut : 
a. Berawal dari depot, kemudian cari lokasi pangkalan dalam suatu clustering yang belum dikunjungi yang memiliki jarak terpendek dari depot. Sebagai lokasi pertama

b. Lanjutkan ke agen lain yang memiliki jarak terdekat dari lokasi yang terpilih sebelumnya dan jumlah pengiriman tidak melebihi kapasitas kendaraan (dalam satu clustering yang sama dengan point (a), lanjutkan ke agen lain yang memiliki jarak paling pendek dari pangkalan terakhir rute berada, lakukan sampai semua agen terkunjungi dalam suatu rute

c. Lakukan langkah (1) dan langkah (2) sampai semua clustering terbentuk rute.

d. Bila semua clustering telah dibuat rute, maka algoritma nearest neighbour berakhir.

10.Perhitungan total jarak untuk semua cluster

Perhitungan total jarak untuk semua cluster dilakukan untuk mengetahui total jarak yang didapat menggunakan rute baru (melalui algoritma sweep)

\subsubsection{Perhitungan Total Biaya Pengiriman (Algoritma Sweep)}

Perhitungan total biaya merupakan ongkos yang harus dikeluarkan oleh perusahaan untuk melakukan pengiriman ke 29 pangkalan, perhitungan ini dilakukan untuk melihat total ongkos yang dihasilkan oleh pembuatan rute mengguanakan algoritma sweep baik jenis backward sweep maupun forward sweep. Perhitungan total biaya pengiriman dapat dilihat pada rumus dibawah ini :

(1)Total Biaya = Biaya pengiriman cluster $1+$ biaya pengiriman cluster $2+\cdots+$

$\cdots$ biaya pengiriman cluster $\mathrm{n}$

(2) Biaya pengriman cluster = biaya bahan bakar + biaya pemberangkatan

(3) Biaya bahan baku = harga 1 liter bahan bakar $\mathrm{x}$ rasio penggunaan bahan bakar

\subsection{Pengolahan Data Rute Perusahaan}

Pengolahan data rute perusahaan saat ini berisikan mengenai perhitungan jarak yang diperoleh untuk setiap rute dan kendaraannya dilanjutkan perhitungan total jarak untuk setiap rute dan armadanya.

1. Perhitungan total jarak untuk setiap rute

2. Perhitungan total jarak untuk setiap rute (cluster) dilakukan dengan melalui bantuan aplikasi Google Maps

3. Perhitungan total jarak untuk semua rute

Perhitungan total jarak untuk semua rute dilakukan dengan cara menjumlahkan total jarak untuk setiap rute yang sudah dihitung pada pengolahan data sebelumnya

\subsubsection{Perhitungan Total Biaya Pengiriman (Rute Perusahaan Saat Ini)}

Perhitungan total biaya merupakan ongkos yang harus dikeluarkan oleh perusahaan untuk melakukan pengiriman ke 29 pangkalan, perhitungan ini dilakukan untuk melihat total ongkos yang dihasilkan oleh rute perusahaan saat ini. Perhitungan total biaya pengiriman dapat dilihat pada rumus dibawah ini :

(1)Total Biaya $=$ biaya pengiriman rute $1+$ biaya pengiriman rute $2+\cdots+\cdots+$ biaya pengiriman cluster $\mathrm{n}$

(2) Biaya pengriman cluster = biaya bahan bakar + biaya pemberangkatan

(3) Biaya bahan baku = harga 1 liter bahan bakar $\mathrm{x}$ rasio penggunaan bahan bakar

\subsection{Analisis}

Analisis berisikan mengenai hasil pengolahan data menggunakan algoritma sweep-nearest neighbour, berisi mengenai total jarak untuk setiap kelompok rute dan total jarak untuk semua rute, waktu tempuh, beserta total biaya pengiriman yang diperlukan untuk memenuhi permintaan setiap agennya untuk selanjutnya dibandingkan dengan hasil perhitungan menggunakan rute perusahaan saat ini.

\subsection{Kesimpulan dan Saran}

Kesimpulan berisikan mengenai perbandingan rute menggunakan algoritma sweep dengan rute perusahaan saat ini, baik dari segi total jarak, total waktu tempuh, total armada yang diperlukan, serta total biaya pengiriman yang dihasilkan untuk masing-masing rutenya dan disimpulkan melalui 
perbandingan total biaya pengiriman yang dihasilkan untuk kedua rute, saran berisikan mengenai rute yang disarankan untuk perusahaan agar mampu melakukan penghematan pada saat pendistribusian produk serta saran untuk penelitian selanjutnya.

\section{HASIL DAN PEMBAHASAN}

\subsection{Data Setiap Pangkalan}

Data lokasi dan permintaan setiap pangkalan dapat dilihat pada Tabel 1

Tabel 1. Data pangkalan PT. Gending Gemilang

\begin{tabular}{|c|c|c|c|c|c|c|c|}
\hline No. & Nama & Alamat & $\begin{array}{l}\text { Alokasi } \\
\text { / Hari }\end{array}$ & No. & Nama & Alamat & $\begin{array}{c}\text { Alokasi / } \\
\text { Hari }\end{array}$ \\
\hline 1 & 31.40201 & $\begin{array}{l}\text { Jl. Ibrahim Aji } \\
\text { No.390 }\end{array}$ & 42 & 16 & Fredy & $\begin{array}{l}\text { Jl. Cigiringsing } \\
\text { Rt. } 05 \text { Rw. } 03\end{array}$ & 147 \\
\hline 2 & 31.40601 & $\begin{array}{c}\text { J1. Sukarno Hatta } \\
\text { No.728 }\end{array}$ & 42 & 17 & $\begin{array}{l}\text { Harun } \\
\text { Ridwan }\end{array}$ & $\begin{array}{l}\text { Jl. Bebedahan - } \\
02 / 03\end{array}$ & 112 \\
\hline 3 & $\begin{array}{c}\text { Aat } \\
\text { Zaelani }\end{array}$ & $\begin{array}{c}\text { Jalan Pesantren } \\
\text { Dalam No. } 7 \text { RT.1 }\end{array}$ & 185 & 18 & Henda & $\begin{array}{l}\text { Jl. Rumah Sakit } \\
\text { No. } 52\end{array}$ & 42 \\
\hline 4 & Ai Juliah & $\begin{array}{l}\text { Jl. SEKE Honje Rt } 1 \\
\text { rw.06 }\end{array}$ & 108 & 19 & H. Lilis & $\begin{array}{l}\text { KP. Karanganyar } \\
1 \text { RT 002/04 }\end{array}$ & 85 \\
\hline 5 & $\begin{array}{l}\text { Asep } \\
\text { Sofyan }\end{array}$ & $\begin{array}{c}\text { KP.TAGOG RT.002 } \\
\text { RW.008 }\end{array}$ & 154 & 20 & Etang & $\begin{array}{l}\text { Jl. Cigagak - } \\
05 / 15\end{array}$ & 116 \\
\hline 6 & Ate & $\begin{array}{c}\text { J1. Trs Pesantren } \\
\text { no. } 73\end{array}$ & 162 & 21 & Jimmy & $\begin{array}{c}\text { Jl. Rereng } \\
\text { Wulung No. } 2\end{array}$ & 187 \\
\hline 7 & $\begin{array}{c}\text { Ayi } \\
\text { Rohmat } \\
\end{array}$ & $\begin{array}{c}\text { J1. Pangaritan Utama } \\
-05 / 07 \\
\end{array}$ & 97 & 22 & Kusaeni & $\begin{array}{c}\text { Cipadung RT } \\
001 / 01 \\
\end{array}$ & 84 \\
\hline 8 & Cristian & $\begin{array}{l}\text { J1. Kiara Asri Raya } \\
\text { no.19 }-01 / 12\end{array}$ & 180 & 23 & Lilih & $\begin{array}{c}\text { Jl. Terusan } \\
\text { Pesantren No. } \\
\text { 23A Rt 3/11 } \\
\end{array}$ & 134 \\
\hline 9 & Dani & $\begin{array}{l}\text { Jl. Pesantren No. } 33 \\
\text { RT. } 03 \text { / } 04\end{array}$ & 162 & 24 & $\begin{array}{l}\text { Nanang } \\
\text { Warman }\end{array}$ & $\begin{array}{l}\text { Jl. DS. Cipadung } \\
78 \text { Rt 002/04 }\end{array}$ & 106 \\
\hline 10 & $\begin{array}{c}\text { Dedi } \\
\text { Junaedi }\end{array}$ & $\begin{array}{l}\text { J1. Andir Wetan RT } \\
002 / 01\end{array}$ & 106 & 25 & Ragil & $\begin{array}{c}\text { MekarMulya } \\
\text { No.28 Rt 002/06 }\end{array}$ & 85 \\
\hline 11 & $\begin{array}{c}\text { Dedi } \\
\text { Sariffudin }\end{array}$ & $\begin{array}{c}\text { Sukaasih GG. Tagog } \\
\text { I RT 005/09 }\end{array}$ & 103 & 26 & Sandy & $\begin{array}{c}\text { Lio Selatan Rt. } \\
004 / 01 \\
\end{array}$ & 135 \\
\hline 12 & $\begin{array}{c}\text { Eden } \\
\text { Kostiawan } \\
\end{array}$ & $\begin{array}{c}\text { Jl. Haruman } 2 \text { no } 7 \text { - } \\
01 / 06\end{array}$ & 106 & 27 & Tuniyah & $\begin{array}{c}\text { Jl. Cijambe No.11 } \\
\text { Rt 1/07 } \\
\end{array}$ & 97 \\
\hline 13 & Ela & $\begin{array}{c}\text { Jl. Margahayuraya } \\
\text { Barat 3-H No.3- } \\
07 / 10 \\
\end{array}$ & 167 & 28 & Vianti & $\begin{array}{l}\text { J1. Pesantren } \\
\text { no. } 75\end{array}$ & 193 \\
\hline 14 & Farlin & $\begin{array}{c}\text { Jl. Cilengkrang } 1 \text { RT } \\
01 / 06\end{array}$ & 108 & 29 & Willy & $\begin{array}{c}\text { J1. Pasir Kaler - } \\
01 / 01\end{array}$ & 85 \\
\hline 15 & Fitri & $\begin{array}{l}\text { J1. Terusan Pesantren } \\
\text { No. } 18 \text { Rt.3/11 }\end{array}$ & 185 & & & Total & 3515 \\
\hline
\end{tabular}

Gambaran visual untuk setiap pangkalan dapat dilihat pada Gambar 3 


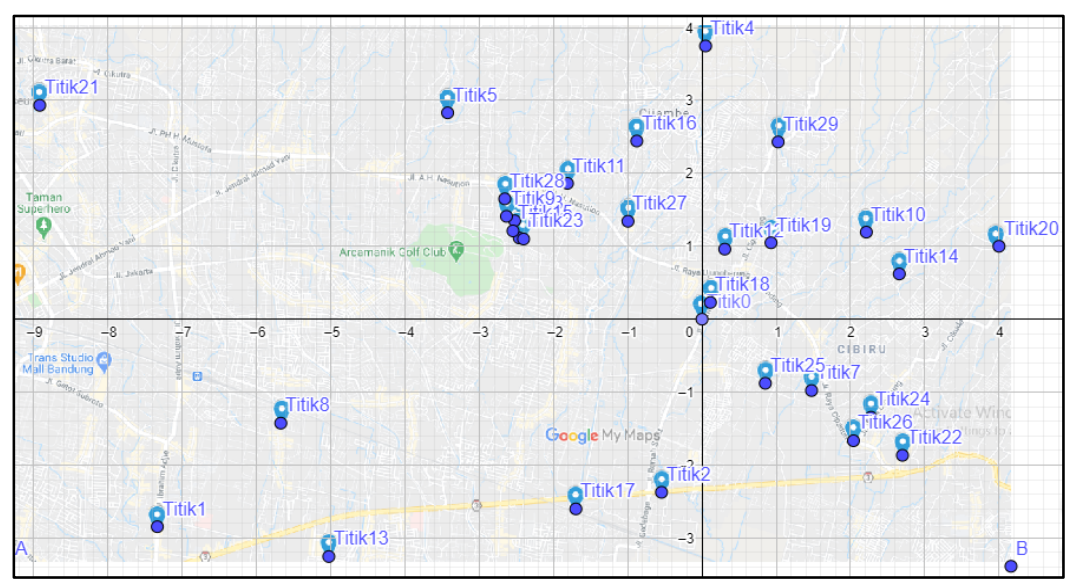

Gambar 3. Gambaran visual setiap pangkalan

\subsection{Biaya Pengiriman}

Biaya pengiriman merupakan biaya yang harus dikeluarkan oleh perusahaan saat melakukan pendistribusian. Perusahaan menetapkan biaya pengiriman menjadi dua jenis yaitu biaya tetap dan biaya tidak tetap, biaya tetap merupakan biaya yang harus dikeluarkan oleh perusahaan yang bersifat tetap setiap bulannya seperti biaya upah sopir sebesar Rp.500.000,00 setiap bulannya, sedangkan untuk biaya tidak tetap merupakan biaya yang harus dikeluarkan perusahaan yang bersifat tergantung jumlah pendistribusian seperti biaya upah sopir per sekali pemberangkatan sebesar Rp.70.000,00 per sekali pendistribusian. Dalam melakukan proses pengiriman, perusahaan menggunakakan 4 armada jenis Truck dan 3 armada jenis L300.

\subsection{Koordinat Kartesius}

Berikut merupakan data koordinat kartesius untuk setiap pangkalannya yang didapat melalui bantuan aplikasi GeoGebra dapat dilihat pada Tabel 2.

Tabel 2. Data koordinat kartesius $\left(^{\circ}\right)$ untuk setiap pangkalan

\begin{tabular}{cccc}
\hline \multicolumn{2}{c}{ Data Koordinat Kartesius } & \multicolumn{2}{c}{ Data Koordinat Kartesius } \\
\hline & $\begin{array}{c}\text { Koordinat } \\
\text { Kartesius }\end{array}$ & Pangkalan & Koordinat Kartesius \\
\hline 1 & $(-7.34,-2.84)$ & 16 & $(-0.88,2.44)$ \\
\hline 2 & $(-0.55,-2.37)$ & 17 & $(-1.7,-2.6)$ \\
\hline 3 & $(-2.52,1.35)$ & 18 & $(0.11,0.23)$ \\
\hline 4 & $(0.05,3.75)$ & 19 & $(0.93,1.05)$ \\
\hline 5 & $(-3.43,2.83)$ & 20 & $(4,1)$ \\
\hline 6 & $(-2.46,1.11)$ & 21 & $(-8.92-2.93)$ \\
\hline 7 & $(1.48,-0.98)$ & 22 & $(2.7,-1.87)$ \\
\hline 8 & $(-5.67,-1.43)$ & 23 & $(-2.4,1.1)$ \\
\hline 9 & $(-2.63,1.41)$ & 24 & $(2.28,-1.34)$ \\
\hline 10 & $(2.21,1.19)$ & 25 & $(0.85,-0.88)$ \\
\hline 11 & $(-1.81,1.86)$ & 26 & $(2.04,-1.67)$ \\
\hline 12 & $(0.31,0.96)$ & 27 & $(-1,1.34)$ \\
\hline 13 & $(-5.03,-3.25)$ & 28 & $(-2.66,1.65)$ \\
\hline 14 & $(2.66-0.62)$ & 29 & $(1.02,2.43)$ \\
\hline 15 & $(-2.55,1.21)$ & &
\end{tabular}




\subsection{Pembuatan Koordinat Polar dan Pengurutan Koordinat Polar}

Pembuatan koordinat polar didapat melalui hasil konversi dari koordinat kartesius menjadi koordinat polar Koordinat polar didapatkan melui bantuan aplikasi Geo Gebra dan setelah diurutkan dapat dilihat pada Tabel 3.

\subsection{Menentukan Prioritas Armada yang Digunakan}

Pada Heterogeneous Fleet Vehicle Routing Problem (MTHFFVRP) mempunyai kapasitas armada yang berbeda-beda untuk setiap jenisnya sehingga perlu dilakukan perhitungan untuk menentukan cost untuk setiap armadanya, perhitungan cost dilakukan untuk dapat menentukan prioritas armada yang harus didahulukan. Berikut merupakan perhitungan cost untuk setiap armadanya dapat dilihat pada Tabel 4.

Tabel 3. Koordinat polar yang telah diurutkan

\begin{tabular}{cccccc}
\hline & \multicolumn{2}{c}{ Data Koordinat Polar $\left(^{\circ}\right)$} & \multicolumn{2}{c}{ Data Koordinat Polar $\left(^{\circ}\right)$} \\
\hline No & Pangkalan & Koordinat Polar $\left(^{\circ}\right)$ & No & Pangkalan & Koordinat Polar $\left(^{\circ}\right)$ \\
\hline 1 & 14 & 13.15 & 16 & 15 & 154.57 \\
\hline 2 & 20 & 14.04 & 17 & 23 & 155.42 \\
\hline 3 & 10 & 28.35 & 18 & 6 & 155.65 \\
\hline 4 & 19 & 48.44 & 19 & 21 & 161.8 \\
\hline 5 & 18 & 63.78 & 20 & 8 & 201.19 \\
\hline 6 & 29 & 67.13 & 21 & 1 & 212.91 \\
\hline 7 & 12 & 72.32 & 22 & 13 & 236.84 \\
\hline 8 & 4 & 89.27 & 23 & 17 & 257.06 \\
\hline 9 & 16 & 109.78 & 24 & 2 & 314.14 \\
\hline 10 & 27 & 126.62 & 25 & 25 & 320.76 \\
\hline 11 & 11 & 134.24 & 26 & 26 & 326.35 \\
\hline 12 & 5 & 140.45 & 27 & 22 & 329.44 \\
\hline 13 & 28 & 148.15 & 28 & 7 & \\
\hline 14 & 9 & 151.83 & 29 & 24 & \\
\hline 15 & 3 & 151.85 & & & \\
\hline
\end{tabular}

Dalam penelitian kali ini untuk penentuan armada yang diprioritaskan untuk digunakan terlebih dahulu hanya memperhatikan ongkos operasional atau variabel cost saja tidak memperhatikan fixed cost. Dari perhitungan cost untuk setiap jenis armadanya didapatkan armada jenis Truck mempunyai nilai yang lebih kecil dari armada jenis L300 sehingga dapat disimpulkan untuk pemilihan armada nantinya diprioritaskan menggunakan armada jenis truck terlebih dahulu, sehingga diharapkan nantinya apabila armada jenis Truck tidak dapat memenuhi semua pangkalan, maka akan menggunakan armada jenis L300 untuk menjangkau pangkalan-pangkalan yang belum terpenuhi sehingga akan menekan total ongkos produksi.

Tabel 4. Perhitungan cost untuk setiap jenis armada

\begin{tabular}{|c|c|c|c|c|c|}
\hline \multirow{2}{*}{ Armada } & \multirow{2}{*}{$\begin{array}{l}\text { Fix } \\
\text { Cost }\end{array}$} & \multicolumn{2}{|c|}{ Variabel Cost } & \multirow{2}{*}{$\begin{array}{l}\text { Kapasitas } \\
\text { Armada }\end{array}$} & \multirow{2}{*}{$\begin{array}{l}\text { Cost / Produk / } \\
\text { Pemberangkatan }\end{array}$} \\
\hline & & Ongkos BBM & Ongkos Pemberangkatan & & \\
\hline Truck & 0 & $5.150 / 6.8 \mathrm{~km}$ & 75.000/Pemberangkatan & 560 & $75.000+(1.352 / \mathrm{Km})$ \\
\hline L300 & 0 & $5.150 / 8 \mathrm{~km}$ & 75.000/Pemberangkatan & 280 & $75.000+(2.299 / \mathrm{Km})$ \\
\hline
\end{tabular}

\subsection{Matriks Jarak dan Matriks Waktu}

Jarak tempuh merupakan data jarak dari satu pangkalan ke pangkalan lainnya, baik dari depot ke agen, maupun jarak dari agen ke agen lainnya, sedangkan Waktu tempuh merupakan waktu yang dibutuhkan untuk untuk berpindah dari satu tempat ke tempat lain. Dalam pengolahan data jarak dan waktu yang dilakukan pada penelitian kali ini, jarak tempuh dan waktu tempuh untuk setiap pangkalannya didapat melalui aplikasi google maps. 


\subsection{Proses Clustering menggunakan Algoritma Sweep}

Pembentukan clustering dimulai armada truck yang mempunyai cost yang lebih kecil dengan metode backward sweep, sehingga untuk proses penyapuan pangkalan dilakukan dari pangkalan yang memiliki sudut polar terbesar (mendekati $360^{\circ}$ ) menuju pangkalan yang memiliki sudut polar terkecil (mendekati $0^{\circ}$ ) dengan memperhatikan kapasitas angkut dan kapasitas waktu. Perusahaan memiliki ketentuan untuk armada jenis Truck maksimal melakukan proses distribusi sebanyak 1 kali pemberangkatan sehingga apabila saat ini armada truck yang tersedia berjumlah 4 buah armada maka pembentukan clustering untuk armada truck hanya bisa dilakukan sebanyak 4 cluster untuk nantinya dilanjutkan menggunakan armada L300. Berikut merupakan rekapitulasi clustering untuk setiap pangkalannya dapat dilihat pada Tabel 5. Berikut merupakan gambaran proses clustering dengan jenis backward sweep dapat dilihat pada Gambar 4

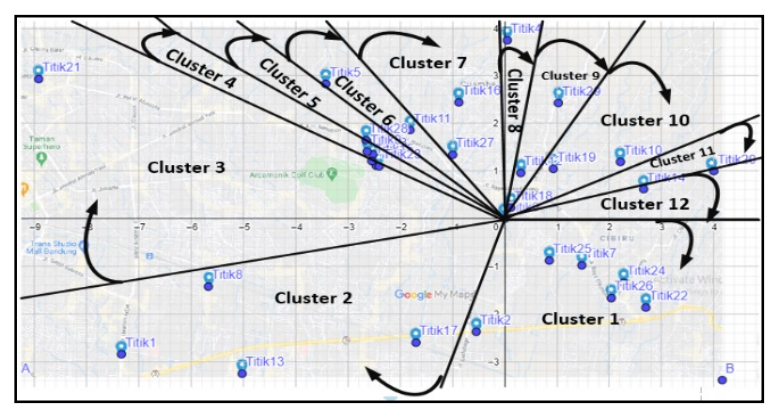

Gambar 4. Proses Sweep Cluster Keduabelas

\subsection{Menentukan Urutan Rute untuk Setiap Cluster}

Dari setiap cluster yang sudah terbentuk, maka langkah selanjutnya ialah menentukan urutan rute yang bertujuan untuk mendapatkan nilai minimal untuk jarak tempuh masing masing clusternya, penentuan rute dilakukan dengan menggunakan nearest neighbour, berikut merupakan rekapitulasi rute menggunakan nearest neighbour untuk setiap cluster armada dapat dilihat pada Tabel 6

Tabel 5. Rekapitulasi clustering untuk setiap armada

\begin{tabular}{|c|c|c|c|c|c|c|c|c|}
\hline \multicolumn{9}{|c|}{ Rekapitulasi Cluster Menggunakan Algoritma Sweep } \\
\hline Cluster & $\begin{array}{c}\text { Jenis } \\
\text { Armada }\end{array}$ & $\begin{array}{c}\text { No. } \\
\text { Armada }\end{array}$ & Tur & Rute & $\begin{array}{l}\text { Jumlah } \\
\text { Angkut }\end{array}$ & $\begin{array}{l}\text { Total } \\
\text { Jarak } \\
(\mathrm{KM})\end{array}$ & $\begin{array}{l}\text { Total } \\
\text { Waktu } \\
\text { Rute } \\
\text { (Jam) }\end{array}$ & $\begin{array}{c}\text { Total Waktu } \\
\text { Armada } \\
\text { (Jam) }\end{array}$ \\
\hline 1 & Truck & 1 & 1 & $\begin{array}{c}0-24-7-22-26- \\
25-2-0\end{array}$ & 549 & 14.65 & 3.928 & 3.928 \\
\hline 2 & & 2 & 2 & $0-17-13-1-8-0$ & 501 & 35.2 & 3.628 & 3.628 \\
\hline 3 & & 3 & 3 & $0-21-6-23-0$ & 483 & 21.615 & 3.028 & 3.028 \\
\hline 4 & & 4 & 4 & $0-15-3-9-0$ & 532 & 7.99 & 2.397 & 2.397 \\
\hline 5 & L300 & 1 & 1 & $0-28-0$ & 193 & 7 & 1.002 & 5.743 \\
\hline 6 & & & 2 & $0-5-11-0$ & 257 & 9.7 & 2.024 & \\
\hline 7 & & & 3 & $0-27-16-0$ & 244 & 10.9 & 1.628 & \\
\hline 8 & & & 4 & $0-4-0$ & 108 & 8.8 & 1.089 & \\
\hline 9 & & 2 & 1 & $0-12-29-18-0$ & 233 & 7.9 & 1.958 & 5.433 \\
\hline 10 & & & 2 & 0-19-10-0 & 191 & 8 & 1.551 & \\
\hline 11 & & & 3 & $0-20-0$ & 116 & 11 & 1.069 & \\
\hline 12 & & & 4 & $0-14-0$ & 108 & 6 & 0.855 & \\
\hline
\end{tabular}


Dari Tabel 6 dapat dilihat pembuatan rute untuk setiap rute, beserta total jarak dan waktu tempuh yang didapat untuk setiap rutenya, dari hasil perhitungan didapat total jarak yang diperoleh ialah sebesar 131,035 Km untuk melakukan pendistribusian Gas LPG 3Kg ke 29 pangkalan yang dimiliki, sedangkan untuk total waktu diperoleh waktu 24,009 Jam.

\subsection{Perhitungan Total Biaya Pengiriman (Algoritma Backward Sweep)}

Perhitungan total biaya dilakukan untuk nantinya melihat total biaya yang harus dikeluarkan oleh perusahaan untuk melakukan proses pendistribusian gas LPG 3Kg ke 29 pangkalan. Perhitungan total biaya pengiriman dapat dilihat pada Tabel 7 .

\subsection{Pengolahan Data Menggunakan Rute Perusahaan Saat Ini}

Saat ini PT. Gending Gemilang mempunyai 13 rute untuk melakukan proses pendistribusian Gas LPG $3 \mathrm{Kg}$ ke 29 pangkalan, 13 rute tersebut terbagi menjadi 4 rute menggunakan armada jenis truck, dan 9 sisanya menggunakan 3 armada jenis L300. Berikut merupakan rekapitulasi jarak untuk setiap rute dapat dilihat pada Tabel 8.

\subsection{Perhitungan Total Biaya Pengiriman (Rute Perusahaan Saat Ini)}

Pada sub-sub bab ini dilakukan perhitungan total biaya pengiriman dari rute perusahaan saat ini. Perhitungan total biaya dilakukan untuk nantinya melihat total biaya yang harus dikeluarkan oleh perusahaan untuk melakukan proses pendistribusian gas LPG 3Kg ke 29 pangkalan. Perhitungan total biaya pengiriman dapat dilihat pada Tabel 9.

Dari hasil perhitungan total biaya untuk masing-masing rute didapatkan total biaya untuk bahan bakar sebesar Rp,91.641,98/hari serta untuk total biaya pemberangkatan sebesar Rp, $840.000,00$ sehingga total biaya keseluruhan untuk rute algoritma backward sweep adalah sebesar Rp,931,641,98/hari, sedangkan untuk rute perusahaan saat ini didapatkan total biaya untuk bahan bakar sebesar Rp,110.886,69/hari serta untuk total biaya pemberangkatan sebesar Rp,910.000,00 sehingga total

biaya keseluruhan untuk rute perusahaan saat ini adalah sebesar Rp,1.020.886,69/hari. Dari kedua nilai yang sudah didapatkan, rute hasil algoritma backward sweep mempunyai total biaya pengiriman yang lebih kecil dengan selisih sebesar Rp, 89.244,72/hari. Lebih kecilnya total biaya pengiriman untuk rute hasil algoritma backward sweep dikarenakan total jarak serta jumlah pemberangkatan rute hasil algoritma sweep lebih kecil dibanding total jarak serta jumlah pemberangkatan dari rute perusahaan saat ini. Berikut merupakan rekapitulasi penghematan rute menggunakan algoritma backward sweep dapat dilihat pada Tabel 10.

Tabel 6. Rekapitulasi rute menggunakan nearest neighbour

\begin{tabular}{|c|c|c|c|c|c|c|c|c|c|}
\hline \multicolumn{10}{|c|}{ Rekapitulasi Cluster Menggunakan Algoritma Sweep - Nearest Neighbour } \\
\hline Cluster & $\begin{array}{c}\text { Jenis } \\
\text { Armada }\end{array}$ & $\begin{array}{l}\text { No. } \\
\text { Ar } \\
\text { ma } \\
\text { da }\end{array}$ & Tur & Rute & $\begin{array}{l}\text { Total } \\
\text { Jarak } \\
(\mathrm{KM})\end{array}$ & $\begin{array}{c}\text { Total } \\
\text { Waktu } \\
\text { Rute } \\
\text { (Jam) }\end{array}$ & $\begin{array}{c}\text { Rute } \\
\text { Nearest } \\
\text { Neighbour }\end{array}$ & $\begin{array}{l}\text { Total } \\
\text { Jarak } \\
(\mathrm{KM})\end{array}$ & $\begin{array}{l}\text { Total } \\
\text { Waktu } \\
\text { Rute } \\
\text { (Jam) }\end{array}$ \\
\hline 1 & \multirow{4}{*}{ Truck } & 1 & 1 & $\begin{array}{l}0-24-7-22- \\
26-25-2-0\end{array}$ & 14.65 & 3.661 & $\begin{array}{l}0-25-7-26- \\
24-22-2-0\end{array}$ & 12.35 & 3.561 \\
\hline 2 & & 2 & 1 & $\begin{array}{c}0-17-13-1- \\
8-0\end{array}$ & 35.2 & 4.261 & $\begin{array}{c}0-17-8-1- \\
13-0\end{array}$ & 21.9 & 3.178 \\
\hline 3 & & 3 & 2 & $\begin{array}{c}0-21-6-23- \\
0\end{array}$ & 21.615 & 3.078 & $\begin{array}{c}0-6-23-21- \\
0\end{array}$ & 21.915 & 3.044 \\
\hline 4 & & 4 & 3 & $0-15-3-9-0$ & 7.99 & 2.397 & $0-9-3-15-0$ & 7.99 & 2.397 \\
\hline 5 & \multirow{3}{*}{ L300 } & \multirow{3}{*}{1} & 1 & $0-28-0$ & 7 & 1.022 & $0-28-0$ & 7 & 1.022 \\
\hline 6 & & & 2 & $0-5-11-0$ & 9.7 & 2.024 & $0-11-5-0$ & 9.7 & 2.024 \\
\hline 7 & & & 3 & $0-27-16-0$ & 10.9 & 1.628 & $0-27-16-0$ & 10.9 & 1.628 \\
\hline
\end{tabular}

Tabel 6. Rekapitulasi rute menggunakan nearest neighbour 


\begin{tabular}{|c|c|c|c|c|c|c|c|c|c|}
\hline Cluster & $\begin{array}{c}\text { Jenis } \\
\text { Armada }\end{array}$ & $\begin{array}{c}\text { No. } \\
\text { Armad } \\
\text { a }\end{array}$ & Tur & Rute & $\begin{array}{l}\text { Total } \\
\text { Jarak } \\
(\mathrm{KM}) \\
\end{array}$ & $\begin{array}{c}\text { Total } \\
\text { Waktu } \\
\text { Rute } \\
\text { (Jam) } \\
\end{array}$ & $\begin{array}{c}\text { Rute Nearest } \\
\text { Neighbour }\end{array}$ & $\begin{array}{l}\text { Total } \\
\text { Jarak } \\
(\mathrm{KM}) \\
\end{array}$ & $\begin{array}{l}\text { Total } \\
\text { Waktu } \\
\text { Rute } \\
\text { (Jam) }\end{array}$ \\
\hline 8 & & & 4 & $0-4-0$ & 8.8 & 1.089 & $0-4-0$ & 8.8 & 1.089 \\
\hline 9 & & 2 & 1 & $0-12-29-18-0$ & 7.9 & 1.958 & $0-29-12-18-0$ & 5.48 & 1.958 \\
\hline 10 & & & 2 & 0-19-10-0 & 8 & 1.551 & $0-19-10-0$ & 8 & 1.551 \\
\hline 11 & & & 3 & $0-20-0$ & 11 & 1.069 & $0-14-20-0$ & 11 & 1.069 \\
\hline \multirow[t]{3}{*}{12} & & & 4 & $0-14-0$ & 6 & 0.855 & $0-14-0$ & 6 & 0.855 \\
\hline & & & & & 148.75 & & & 131.0 & \\
\hline & & & & Total & 5 & 24.593 & & 35 & 23.375 \\
\hline
\end{tabular}

Berdasarkan hasil perbandingan untuk kedua rute dari segi total jarak, jumlah armada yang digunakan, total waktu tempuh, serta total biaya pengiriman didapatkan rute dengan menggunakan algoritma backward sweep memiliki rute yang lebih baik dari rute perusahaan saat ini baik dari segi total jarak, total waktu tempuh, jumlah armada yang digunakan, mapun dari segi total biaya pengiriman. rute menggunakan algoritme backward sweep mampu menghasilkan penghematan sebesar Rp, 89.244,72 setiap harinya, dari segi total jarak rute menggunakan algoritma backward sweep mampu melakukan penghematan sebesar $18,56 \%$ dari rute perusahaan saat ini, selain itu rute menggunakan algoritma backward sweep mampu melakukan penghematan jumlah armada sebanyak satu buah armada jenis L300 sehingga dengan penghematan jumlah armada tersebut perusahaan nantinya dapat memperbanyak jumlah pangkalan yang tentunya akan menambah keuntungan untuk perusahaan. Berikut merupakan rekapitulasi rute terpilih menggunakan algoritma backward sweep dapat dilihat pada Tabel 11.

Tabel 7. Rekapitulasi total biaya pengiriman (algoritma backward sweep)

\begin{tabular}{|c|c|c|c|c|c|c|c|c|c|}
\hline Cluster & $\begin{array}{c}\text { Jenis } \\
\text { Armad } \\
\text { a }\end{array}$ & $\begin{array}{l}\text { No. } \\
\text { Arma } \\
\text { da }\end{array}$ & Tur & Rute & $\begin{array}{l}\text { Total } \\
\text { Jarak } \\
(\mathrm{KM})\end{array}$ & $\begin{array}{l}\text { Rasio } \\
\text { BBM }\end{array}$ & $\begin{array}{c}\text { Biaya Bahan } \\
\text { Bakar }\end{array}$ & $\begin{array}{c}\text { Biaya } \\
\text { Pemberan } \\
\text { gkatan }\end{array}$ & $\begin{array}{c}\text { Biaya } \\
\text { Keseluruha } \\
n\end{array}$ \\
\hline 1 & \multirow{4}{*}{ Truck } & 1 & 1 & $\begin{array}{l}0-25-7-26- \\
24-22-2-0\end{array}$ & 12.35 & \multirow{4}{*}{$\begin{array}{c}5150 / 6 . \\
8 \mathrm{Km}\end{array}$} & 9353.309 & 70000 & 79353.309 \\
\hline 2 & & 2 & 1 & $\begin{array}{c}0-17-8-1-13- \\
0\end{array}$ & 21.9 & & 16586.029 & 70000 & 86586.029 \\
\hline 3 & & 3 & 1 & $0-6-23-21-0$ & $\begin{array}{c}21.91 \\
5\end{array}$ & & 16597.390 & 70000 & 86597.390 \\
\hline 4 & & 4 & 1 & $0-9-3-15-0$ & 7.99 & & 6051.250 & 70000 & 76051.250 \\
\hline 5 & \multirow{9}{*}{ L300 } & \multirow{4}{*}{1} & 1 & $0-28-0$ & 7 & \multirow{9}{*}{$\begin{array}{c}5.150 / 8 \\
\mathrm{Km}\end{array}$} & 4506.250 & 70000 & 74506.250 \\
\hline 6 & & & 2 & $0-11-5-0$ & 9.7 & & 6244.375 & 70000 & 76244.375 \\
\hline 7 & & & 3 & $0-27-16-0$ & 10.9 & & 7016.875 & 70000 & 77016.875 \\
\hline 8 & & & 4 & $0-4-0$ & 8.8 & & 5665.000 & 70000 & 75665.000 \\
\hline 9 & & \multirow{5}{*}{2} & 1 & $\begin{array}{c}0-29-12-18- \\
0\end{array}$ & 5.48 & & 3527.750 & 70000 & 73527.750 \\
\hline 10 & & & 2 & 0-19-10-0 & 8 & & 5150.000 & 70000 & 75150.000 \\
\hline 11 & & & 3 & $0-20-0$ & 11 & & 7081.250 & 70000 & 77081.250 \\
\hline 12 & & & 4 & $0-14-0$ & 6 & & 3862.500 & 70000 & 73862.500 \\
\hline \multicolumn{4}{|c|}{ Total } & & & & 91641.98 & 840000 & 931641.98 \\
\hline
\end{tabular}


Penyelesaian Multiple Trip Heterogeneous Fix Fleet Vehicle Routing Problem (MTHFFVRP) Menggunakan Algoritma Sweep untuk Mendapatkan Optimasi Rute Distribusi LPG $3 \mathrm{~kg}$ di PT. Gending Gemilang

Tabel 8. Rekapitulasi perhitungan jarak untuk setiap rute saat ini

\begin{tabular}{|c|c|c|c|c|c|}
\hline \multicolumn{6}{|c|}{ Rekapitulasi Perhitungan Jarak Semua Rute Saat Ini } \\
\hline Rute & $\begin{array}{c}\text { Jenis } \\
\text { Armada }\end{array}$ & Urutan Rute & $\begin{array}{l}\text { Jumlah } \\
\text { Produk }\end{array}$ & Total Jarak (Km) & $\begin{array}{c}\text { Total Waktu } \\
\text { (Jam) }\end{array}$ \\
\hline 1 & \multirow{9}{*}{ L300 } & $0-1-2-0$ & 84 & 19.1 & 1.697 \\
\hline 2 & & $0-25-7-19-0$ & 267 & 6.75 & 1.900 \\
\hline 3 & & $0-26-20-0$ & 251 & 11.6 & 1.722 \\
\hline 4 & & $0-17-29-0$ & 197 & 13.8 & 1.712 \\
\hline 5 & & $0-16-27-0$ & 244 & 10.9 & 1.661 \\
\hline 6 & & $0-10-11-0$ & 209 & 14.2 & 1.983 \\
\hline 7 & & $0-24-22-0$ & 190 & 8.5 & 1.450 \\
\hline 8 & & $0-5-0$ & 154 & 9.4 & 0.870 \\
\hline 9 & & $0-12-0$ & 106 & 2.4 & 0.619 \\
\hline 10 & \multirow{4}{*}{ Truck } & $0-8-13-21-0$ & 534 & 35.4 & 3.751 \\
\hline 11 & & $0-3-6-9-0$ & 509 & 8.12 & 2.356 \\
\hline 12 & & $0-15-23-28-0$ & 512 & 8.361 & 2.429 \\
\hline 13 & & 0-14-4-18-0 & 258 & 12.38 & 2.284 \\
\hline \multicolumn{3}{|c|}{ Total } & 3515 & 160.911 & 24.434 \\
\hline
\end{tabular}

Tabel 9. Rekapitulasi total biaya pengiriman (rute perusahaan saat ini)

\begin{tabular}{|c|c|c|c|c|c|c|c|}
\hline Rute & $\begin{array}{l}\text { Jenis } \\
\text { Armada }\end{array}$ & Rute & $\begin{array}{l}\text { Total } \\
\text { Jarak } \\
(\mathrm{KM})\end{array}$ & $\begin{array}{c}\text { Rasio } \\
\text { Penggunaan } \\
\text { Bahan Bakar } \\
(1 \text { liter }= \\
\text { Rp.5.150,00) }\end{array}$ & $\begin{array}{c}\text { Biaya Bahan } \\
\text { Bakar }\end{array}$ & $\begin{array}{c}\text { Biaya } \\
\text { Pember } \\
\text { angkata } \\
n\end{array}$ & $\begin{array}{c}\text { Biaya } \\
\text { Keseluruhan }\end{array}$ \\
\hline 1 & \multirow{9}{*}{ L300 } & $0-1-2-0$ & 19.1 & \multirow{9}{*}{$5150 / 8 \mathrm{KM}$} & 12295.63 & 70000.00 & 82295.63 \\
\hline 2 & & $\begin{array}{c}0-25-7-19- \\
0\end{array}$ & 6.75 & & 4345.31 & 70000.00 & 74345.31 \\
\hline 3 & & $0-26-20-0$ & 11.6 & & 7467.50 & 70000.00 & 77467.50 \\
\hline 4 & & $0-17-29-0$ & 13.8 & & 8883.75 & 70000.00 & 78883.75 \\
\hline 5 & & $0-16-27-0$ & 10.9 & & 7016.88 & 70000.00 & 77016.88 \\
\hline 6 & & $0-10-11-0$ & 14.2 & & 9141.25 & 70000.00 & 79141.25 \\
\hline 7 & & $0-24-22-0$ & 8.5 & & 5471.88 & 70000.00 & 75471.88 \\
\hline 8 & & $0-5-0$ & 9.4 & & 6051.25 & 70000.00 & 76051.25 \\
\hline 9 & & $0-12-0$ & 2.4 & & 1545.00 & 70000.00 & 71545.00 \\
\hline 10 & \multirow{5}{*}{ Truck } & $\begin{array}{c}0-8-13-21- \\
0\end{array}$ & 35.4 & \multirow{5}{*}{$5150 / 6.8 \mathrm{KM}$} & 26810.29 & 70000.00 & 96810.29 \\
\hline 11 & & $0-3-6-9-0$ & 8.12 & & 6149.71 & 70000.00 & 76149.71 \\
\hline 12 & & $\begin{array}{c}0-15-23- \\
28-0\end{array}$ & 8.361 & & 6332.23 & 70000.00 & 76332.23 \\
\hline 13 & & $\begin{array}{c}0-14-4-18- \\
0\end{array}$ & 12.38 & & 9376.03 & 70000.00 & 79376.03 \\
\hline \multicolumn{3}{|r|}{ Total } & & & 110886.69 & 910000.00 & 1020886.69 \\
\hline
\end{tabular}

Tabel 10. Rekapitulasi penghematan rute menggunakan algoritma backward sweep

\begin{tabular}{ccc}
\hline & Penghematan Rute Algoritma Sweep \\
\hline & Rute Saat Ini & Rute Baru Menggunakan Algoritma Sweep \\
\hline Total Biaya (Rp) & 1020886.69 & 931641.98 \\
\hline Penghematan / Hari (Rp) & \multicolumn{2}{c}{89244.72} \\
\hline
\end{tabular}


Tabel 11. Rekapitulasi rute terpilih menggunakan algoritma backward sweep

\begin{tabular}{|c|c|c|c|c|}
\hline Cluster & $\begin{array}{c}\text { Jenis } \\
\text { Armada }\end{array}$ & No. Armada & Tur & Rute \\
\hline 1 & \multirow{4}{*}{ Truck } & 1 & 1 & $0-25-7-26-24-22-2-0$ \\
\hline 2 & & 2 & 1 & $0-17-8-1-13-0$ \\
\hline 3 & & 3 & 1 & $0-6-23-21-0$ \\
\hline 4 & & 4 & 1 & $0-9-3-15-0$ \\
\hline 5 & \multirow{8}{*}{ L300 } & \multirow{4}{*}{1} & 1 & $0-28-0$ \\
\hline 6 & & & 2 & $0-11-5-0$ \\
\hline 7 & & & 3 & $0-27-16-0$ \\
\hline 8 & & & 4 & $0-4-0$ \\
\hline 9 & & \multirow{4}{*}{2} & 1 & $0-29-12-18-0$ \\
\hline 10 & & & 2 & $0-19-10-0$ \\
\hline 11 & & & 3 & $0-20-0$ \\
\hline 12 & & & 4 & $0-14-0$ \\
\hline
\end{tabular}

\section{KESIMPULAN}

Total biaya pendistribusian berdasarkan hasil perhitungan algoritma sweep serta rute perusahaan saat ini, rute menggunakan algoritma backward sweep menghasilkan nilai yang lebih baik dari rute perusahaan saat ini. Dari segi total biaya pendistribusian rute menggunakan algoritma backward sweep mampu melakukan penghematan sebesar Rp, 89.244,72/hari atau sebanyak Rp, 2.320.362,64/bulan dari rute perusahaan saat ini, dan jumlah armada yang digunakan berjumlah 4 Truck dan 2 L300 dengan pengefisiensian total jarak sebesar $18,56 \%$.

\section{DAFTAR PUSTAKA}

[1] Toth, P. \& Vigo, D. (2002). The Vehicle Routing Problem, Society for Industrial and Applied Mathematics, Second Edition. Philadelphia: SIAM.

[2] Gitiza Erwitie. (2020). Perencanaan Rute Distribusi Bantuan Bencana Tsunami Di Kota Padang dengan Multi-Trip Heterogeneous Fixed Fleet Vehicle Routing Problem (MTHFFVRP) Berdasarkan Geographic Information System (GIS). Jakarta : Universitas Pertamina.

[3] Arunya Boonkleaw, S. Suthikannarunai, \& R. Srinon. (2009). Strategic Planning and Vehicle Routing Algorithm for Newspaper Delivery Problem: Case Study of Morning Newsppaper, Bangkok, Thailand. Proceeding of the World Congress on Engineering and Computer Science, Sanfranciso, USA. Vol. 2

[4] Pujawan, I., N., \& Mahendrawathi. (2017). Supply Chain Management, Edisi Ketiga. Yogyakarta: Andi.

[5] Sandy Satria (2016). Analisis Rantai Distribusi Komoditas Padi dan Beras di Kecamatan Jatiwangi Kabupaten Sumedang. Bandung : Universitas Pasundan

[6] Risky Sarasvati. (2017). Penyelesaian Capacitated Routing Problem (CVRP) Menggunakan Algoritma Sweep Untuk Penentuan Rute Distribusi Koran. Surakarta : Universitas Sebelas Maret

[7] Ramayanti Rizka. (2019). Penerapan Algoritma Sweep untuk Penyelesaian Open Vehicle Routing Problem pada Kasus Distribusi Produk. Jember : Universitas Jember

[8] Raden A. Laksono. (2015). Analisi Biaya Operasional Kendaraan (BOK) dan Tingkat Okupansi Angkutan Taksi Daerah Istimewa Yogyakarta. Yogyakarta : Universitas Atma Jaya 